\title{
樹林が繁茂した加古川中流部における 出水時流況と樹林損壊に関する調査・解析 \\ ANALYSIS ON RECENT FLOOD EVENTS AND TREE VEGETATION COLLAPSES IN KAKO RIVER
}

道奥康治 1 ・宮本仁志 $2 \cdot$ 神田佳一 $3 \cdot$ 大地洋平 4 ・阿河一穂 4 盛岡淳二 4 ・ 魚谷拓矢 $5 \cdot$ 吉田一亮 $6 \cdot$ 吉村敏 6

Kohji MICHIOKU, Hitoshi MIYAMOTO, Keiichi KANDA, Yohei OHCHI, Kazuho AGA, Jyunji MORIOKA, Takuya UOTANI, Kazuaki YOSHIDA, Satoshi YOSHIMURA

\author{
1フェロー会員 工博 神戸大学大学院教授 工学研究科（戸657-8501 神戸市灘区六甲台町1-1） \\ 2正会員 博(工) 神戸大学大学院准教授 工学研究科（二657-8501 神戸市灘区六甲台町1-1） \\ 3 正会員 博(工) 舞鶴工業高等専門学校教授 建設システム工学科（† 625-8511 舞鶴市字白屋234） \\ 4学生員 神戸大学大学院学生 工学研究科（†657-8501 神戸市灘区六甲台町1-1） \\ 5学生員 明石工業高等専門学校学生 建築都市システム工学専攻（†674-8501 明石市魚住町西岡679-3） \\ 6 国土交通省姫路河川国道事務所（广670-0947 兵庫県姫路市北条1-250）
}

\begin{abstract}
Forestation on flood plains is a world-wide engineering issue in middle to downstream reaches in many rivers. This brings not only degradation of flow conveyance capacity but also irreversible changes of ecological system in rivers. In order to obtain information on tree vegetation behavior during flood events, field data of flow fields and tree vegetation collapse were collected in Kako River, where willows are heavily vegetated on the flood plain. After starting a H-ADCP flow measurement in 2009, small to medium size flood events frequently occurred, which enables us not only to verify an analytical model to reproduce flow fields in and out of vegetations but also to examine tree vegetation collapses after flooding. The analytical solutions on velocity profiles as well as flow force acting on trees were in good agreement with the H-ADCP measurements and tree damages, respectively.
\end{abstract}

Key Words : Willow vegetated river, $H$-ADCP, flood flow analysis, tree collapse

\section{1. はじめに}

治水・利水を目的として人為的に改変された河川の中 下流部では，陸地化や植生繁茂の進行が国内外で顕在化 している．砂碩で覆われたかつての"White River"から河 川敷が緑に覆われた"Green River"への移行として象徵的 に取り扱われている. 植生繁茂の中でも樹林化は特に, 疎通障害や流木生産を助長して河道の治水機能を低下さ せ，水際遷移帯の喪失など環境システムの不可逆的変化 をもたらす．樹林化の要因としては，河川の自然営力に 見合わない河道断面や流量の人為制御などによる流況の 平準化が疑われており, 河川流の自然擋乱によって樹林 化が抑制されるように河川の再整備を進め，それに応じ た管理を実施することが求められている. しかし，出水 時の河川流と樹林動態を同時に連続計測した事例が少な く, 河川のダイナミズムを生かせるような河道断面の適 正化に関する知見は十分に得られていない，そのため， 樹林河道の問題を取り扱ったこれまでの数值解析, 水理 実験，樹木の消長に関する調查などによる成果 ${ }^{1,2,2,3,4)}$ 出水時の流況や植生動態に基づいて検証することは困難
であり, 必ずしも既往の研究で得られた知見が樹林化抑 制の施策に反映されているとは言えない現状にある．河 道の適正な管理には，樹林化河道の流孔を解析する水理 学的なアプローチと樹木の消長を考慮した植生生態学的 なアプローチ5が必要である.

著者らは, 水理学的なアプローチとして, 横断方向の 流速分布の連続計測が可能なH-ADCPシステムを2009年 5月から加古川中流部に設置し6)，2009年8月～2010年5月 の4回にわたる中小規模の出水を捉えることに成功した. この期間において，同時にヤナギ・竹などの樹径・樹 高・繁茂密度などの樹木特性と出水後の倒伏・損壊状況 を集中的に調査した．現地観測で得られた流速と樹木損 壊との因果関係を検証するためには，樹林内外の流れと 流体力を再現し得る数值解析が必要である. そこで, 樹 林帯のような透過性領域が河川流の一部に含まれ，しか も水位変動にともない樹林の一部あるいは全域が冠水す るような流れを再現するために，透過構造物の流れを対 象として開発された二次元二層流モデル7を基にして, 樹林内外の流れと流体力・林床に作用寸る河床せん断力

（以下，「林床せん断力」と記す）を解析できる数值計 算手法を構築した。本論文では，4回の出水現象をこの 
数值解析モデルにより再現し, 樹林調査や洪水観測から 明らかとなった樹林損壊の実績と流れの観測結果との比 較からその有效性を検証するとともに，樹林の損壊义カ ニズムについて考察する.これにより, 樹林化が進行し た河川の整備・管理方針に関する知見を得ることを研究 の目的とする.

\section{2. 平面二次元二層流モデルの特徵6)}

解析に用いたモデルは，図-1に示寸ような，水位・樹 高が時空間的に変化する河川流を想定した二次元二層流 モデルである. 全解析領域を「樹林 - 水」で構成される 混相流と「水一水」で構成される単相流の領域に区分す る．樹冠をつなぐ界面で流れを上下二層に分割し，樹冠 境界（内部せん断層）に発生寸る内部せん断力や質量 運動量交換をモデル化することによって，樹林を透過・ 越流寸る流れを再現できる，樹林層内では，流速・水位 に加えて樹木に作用する流体抗力と林床せん断力の解が 同時に得られる. 樹木の流体抗力は次式で与えられる.

$$
\left(F_{\mathrm{x}}, F_{\mathrm{y}}\right)=\frac{\rho C_{\mathrm{D}} \lambda_{\text {veg }} h_{\mathrm{v}} \sqrt{u^{2}+v^{2}}}{2}(u, v)
$$

ここで, $\left(F_{\mathrm{x}}, F_{\mathrm{y}}\right)$ 流体抗力の $\mathrm{x}, \mathrm{y}$ 方向成分， $(u, v)$ :層平均流 速のx,y方向成分, $h_{\mathrm{V}}$ :樹林の浸水高さ, $\lambda_{\text {veg }}$ : 密生度, $C_{\mathrm{D}}$ : 樹木の抗力係数 ${ }^{8}$ (密生度と樹径の関数) である.また, 出水時の水位変動にも適用可能で, 倒伏・成長にともな い様々な高さの植物が分布する状況を再現し, 柔軟かつ 合理的に機能寸る．なお，本研究では，実績洪水を対象 としたため, 樹林が冠水しない一層流として表現されて いる. 計画規模相当の出水の場合には樹林が完全に冠水 するため, 二層流として解析した゚).

\section{3. 対象区間における出水観測}

出水観測は，図-2に示寸加古川の河口から23.0-24.4km の中流部に位置する樹林繁茂区間を対象とした．同区間 のセグメントは2-1に分類される．ここでは，冠水を促 進して植生の新規参入と樹林化を抑制することを目的と して，2008年3月に図-2中に示寸高水敷の一部が試験的 に切り下げられている（写真-1，2参照）。また，砂州 上の優先樹種であるヤナギと竹を対象として植生調查を 実施した. 出水時における横断方向流速分布を連続計測 するため, 切り下げ区間の横断面に超音波ドップラー式 流速計（以下，「H-ADCP」と記す）を設置した（写真3参照）。2009年8月1-2日，同年8月10日，2010年4月1213 日, 同年5月23-25日の計4回, 中小規模の洪水が発生 した. 写真-4のように試験区間の高水敷や樹林の一部が 冠水し，H-ADCPによる流速計測に成功した。 これら各

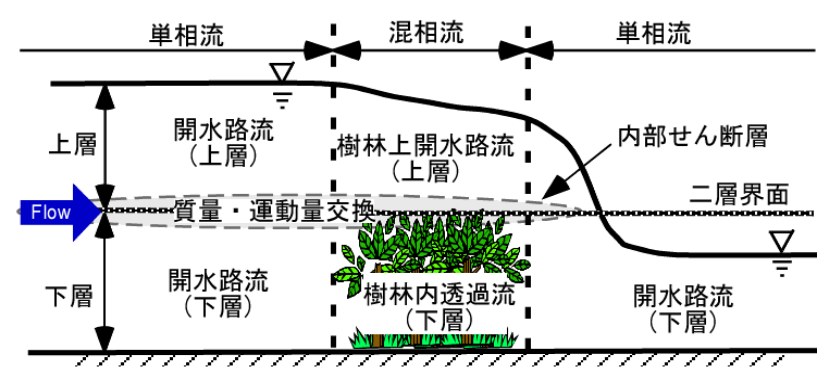

図-1 二次元二層流モデル

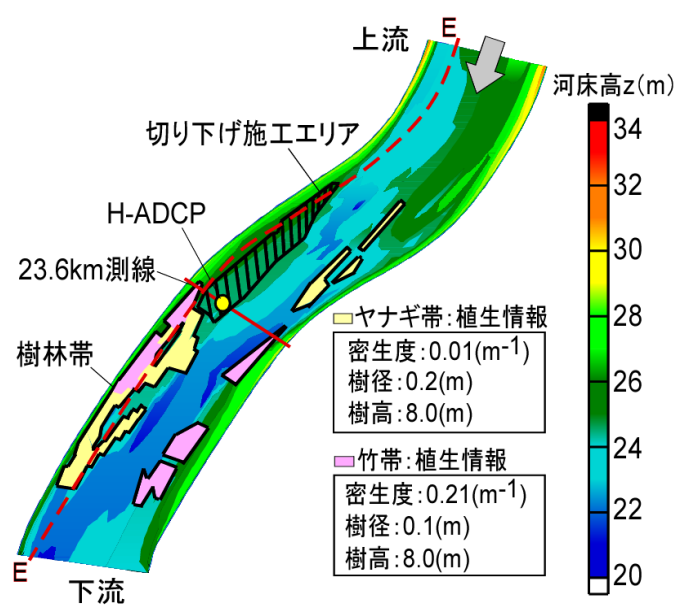

図-2 解析および調査対象区間
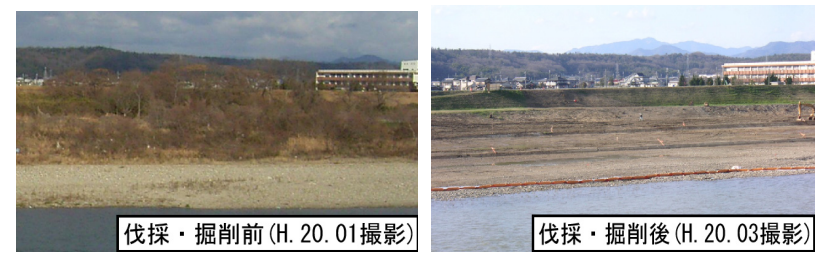

写真-1 切り下げ前

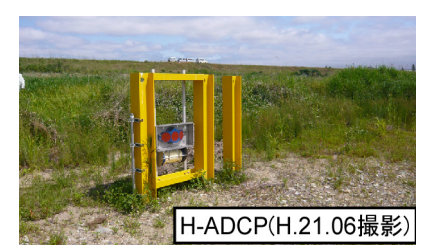

写真-2 切り下げ後

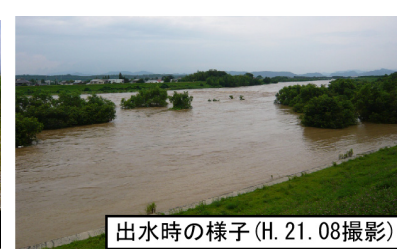

写真-3 H-ADCP 写真-4 出水の様子(H.21年8月2日)

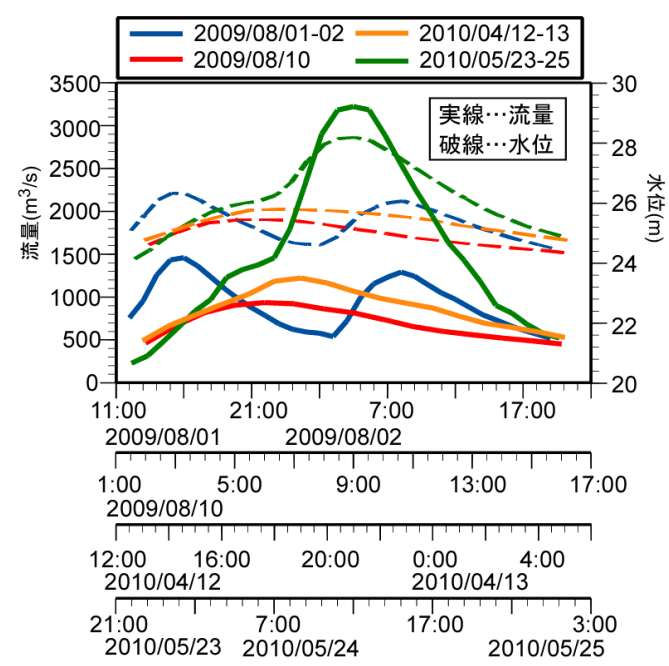

図-3 観測された洪水の流量 · 水位変化 
出水後ならびに季節毎に右岸で樹林帯の現地踏査を行い, 樹高・樹径・繁茂密度や倒伏状況等を調査した．また， 23.6km測線上の両岸に水位計を設置することで，水位計 測を行っている.

\section{4. 数値モデルによる出水流況の再現と検証}

\section{(1) 概要}

H-ADCPによって流速が観測された4回の出水におけ るハイドログラフと水位の記録を図-3に示す，対象区間

（23.0km-24.4km）における流量は，それより $3 \mathrm{~km}$ 下流 の大島観測所の流量記録と，その間に合流寸る右支川万 願寺川の流量（万願寺観測所）との差加推定した. こ れを上流端での境界条件として与え，下流端境界では $23.6 \mathrm{~km}$ の地点の水位実測值から河床勾配 $1 / 800$ を考慮し て水位を推定し与える.

\section{(2) 流れの再現と考察}

\section{a) $\mathrm{H}-\mathrm{ADCP}$}

図-4に2009年8月1-2日においてH-ADCPに記録された 超音波反射強度を示寸．所定の流速精度を得るためには 約60dB以上の有効反射強度が必要であるが，これより 小さい場合は流速信号が乱れ十分な計測精度が得られな い. この出水では, 有効な測定範囲がH-ADCP設置位置 から横方向に30-60m程度と判断される．ここで，左岸に 近いほど乱れが大きい原因として，浮遊する細粒土砂や ゴミ・流木等の夾雑物により，超音波が遮断された影響 が考えられる. 他の3回の出水に関しても, 測定された 超音波反射強度加分な信頼性と判断される有効測定 範囲の計測值のみを数值解析との比較検証に用いる.

\section{b) 解析値とH-ADCP観測值との比較}

数值解析により再現された $23.6 \mathrm{~km}$ 測線上における流速 とH-ADCP計測值との比較を図-5に示す。ここで，横軸 は日時, 縦軸は右岸からの横断距離を示している. 図中, 左岸側の点線で囲まれた領域は，有効反射強度が $60 \mathrm{~dB}$ 以下で十分な測定精度が得られていない領域に相当し， それ以外の範囲の計測值と数值解析值とを比較する.

2009年8月1-2日，8月10日，2010年4月12-13日の計測值に 関しては, 有效測定範囲の流速は数值解析值と概ね一致 している. しかし，4回の出水の中で最もピーク流量の 大きい2010年5月23-25日の観測に関しては，流速分布の 特徵が概ね一致してはいるものの, 他の出水と比較する と数值解析值が過小評価されている. その原因としては, 樹高を一様に与えたことで水位が高い5月出水での低水 路内の流れを過小評価したこと, 他の出水よりも濁度が 高く H-ADCP超音波が阻害され，有効計測範囲が狭くな るとともに左岸側の計測精度が低下したことなどが考え られる. また，この地点でのハイドログラフ推定に用い た流量観測所におけるこの規模の流量のH-Q特性や現地

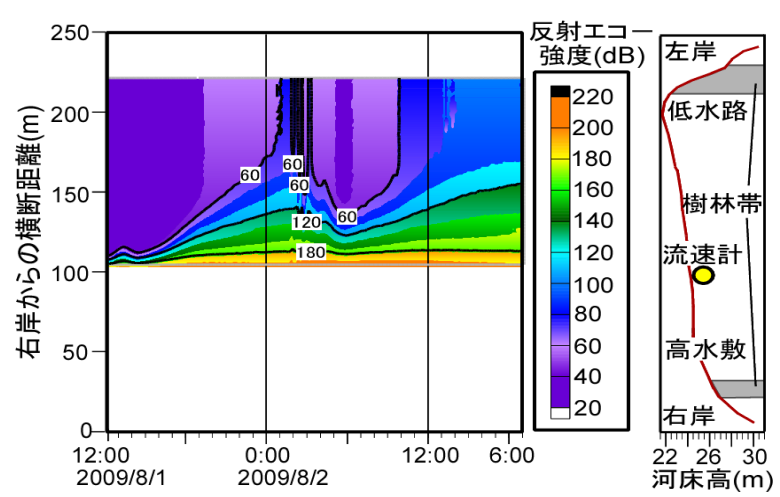

図-4 超音波反射強度の例

に即した左岸樹林データを与えるなどの検証が必要と考 えている. しかし, 流量の増減にともなう流速の経時変 化や横断分布特性に関しては概ね再現されており, 本モ デルの流況再現性が認められる.

\section{c）樹林帯の有無が流況に与える影響}

研究対象区間では, ヤナギ・竹林が両岸に繁茂し, 疎 通能力に大きく影響していると考えられる. そこで, 樹 林が出水流況に及ぼす影響を確認するために，樹林帯が 存在する場合（現況）と樹林帯が存在しないと仮定した 場合の $23.6 \mathrm{~km}$ 測線上における平均流速分布を河床横断形 状とともに図-6に示寸 (樹林帯の位置は同図中にグレー ゾーンで示されている）。現況のように樹林帯の存在す る場合には，樹林帯内部での減速や踈通障害のために主 流の低水路部分に流れが集中して，樹林帯がない場合よ りも「低水路一高水敷」間の流速差が大きい，このような 流速分布の傾向は低水路河床を侵食し, 高水敷一の土砂 輸送と堆積をもたらす方向に作用し，陸地化・樹林化を 促進する要因と推察される. 流速の解析結果は, 定量的 にもH-ADCPの観測值とも概ね一致しており，本モデル の現況再現性を改めて確認することができる. ただし， 左岸側の流速が乱れている範囲では, 前述のように計測 誤差が大きくなるため一致していない.

\section{4. 平成16年23号台風を対象とした樹木倒伏実績 の検証}

\section{（1）現地踏査}

樹林繁茂状況を把握するために右岸を中心として, 2009年〜2010年の各出水後と季節の節目において現地調 查を実施した．図-7に調查結果である樹木の生育状況を 示寸，砂州上のヤナギは主流部に近いほど樹径が小さい． これは, 出水毎に流水擋乱を受けて倒伏・伐根を繰り返 し，残った根茎から，あるいは新規に発芽・生長を開始 するためであると考えられる. すなわち, 洪水撹乱を受 ける領域においては，陸上部の樹齢が若く樹径の小さな 樹木が多く分布するものと考えられる.この領域では, 倒伏履歴を有するヤナギが多く分布し, 樹径が $50 \mathrm{~cm}$ 
超えるヤナギの倒伏痕跡も確認された。これに対し，堤 防側に近く地盤が高い砂州領域では，樹径が比較的大き なヤナギの分布が目立っている。この領域では流れの影 響を受けにくいため，ヤナギの損壊は顕著でないと考え られる. しかし，これら今回の現地踏査で倒伏履歷が確 認された樹木の大部分は, 洗掘部に他の草木がすでに活 着していること, 付着ゴミが古いこと, 幹や枝の倒伏・ 傾斜後の天空方向への延伸が見られること，幹に植物が 絡みついていること等から，2009年よりも以前に倒伏し
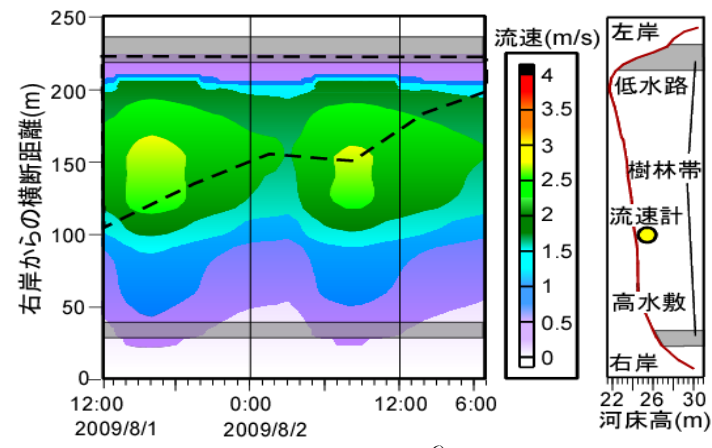

(a) 2009/8/1-2 解析値 ${ }^{6}$

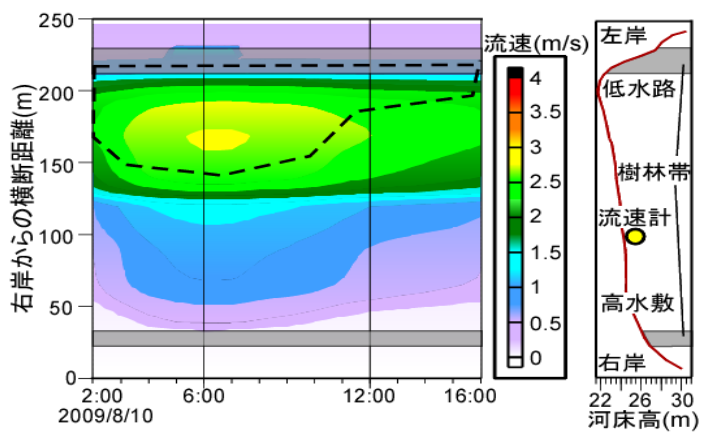

(c) 2009/8/10 解析值

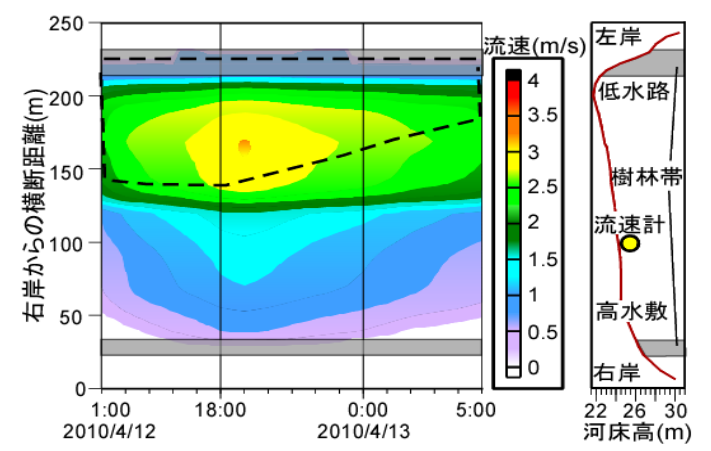

(e) 2010/4/12-13 解析値

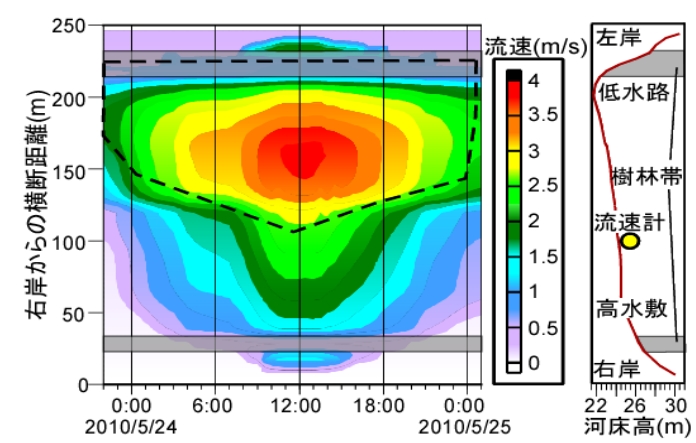

(g) 2010/5/24-25 解析値
ていると推察された。 また，主流部近傍では樹噛5年以 下の0-10cmの非倒伏樹木が多く確認されたことから，過 去5年以内の出水により倒伏した樹木から栄養繁殖によ り生長したものが多い. よって, 倒伏履歴を有する樹木 の大部分が過去 5 年以内で最も大きな出水を記録した平 成16年23号台風により倒伏したと仮定し，この出水で樹 木に作用した流体力を数值解析により再現する. 解析に 際しては, この出水の実績流量 $4,400 \mathrm{~m}^{3} / \mathrm{s}$ と下流端水位 $30.4 \mathrm{~m}$ を境界条件して用いた。

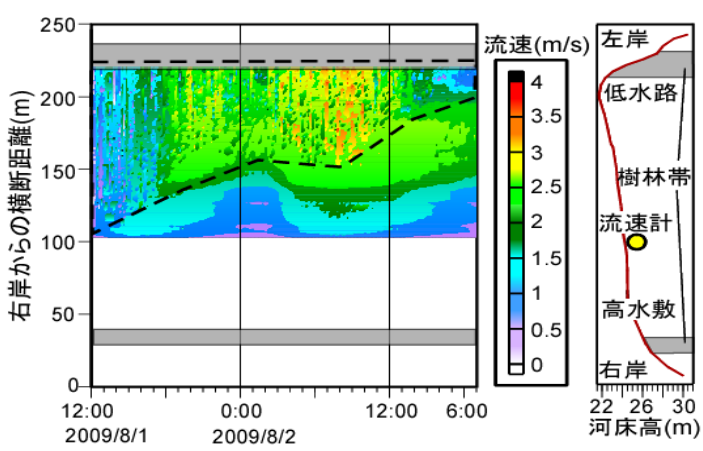

(b) 2009/8/1-2 観測値 ${ }^{6}$

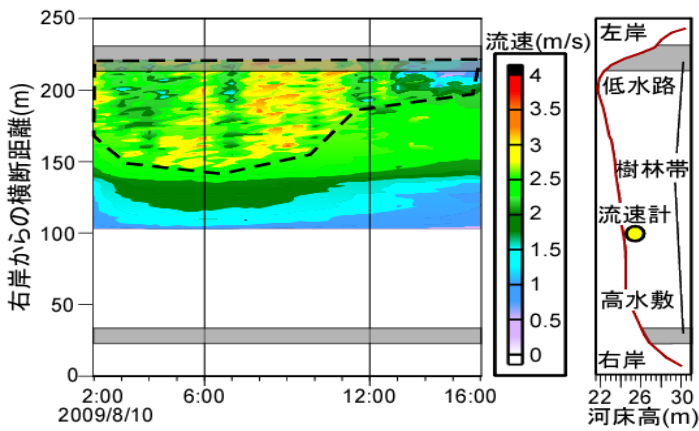

(d) 2009/8/10 観測値

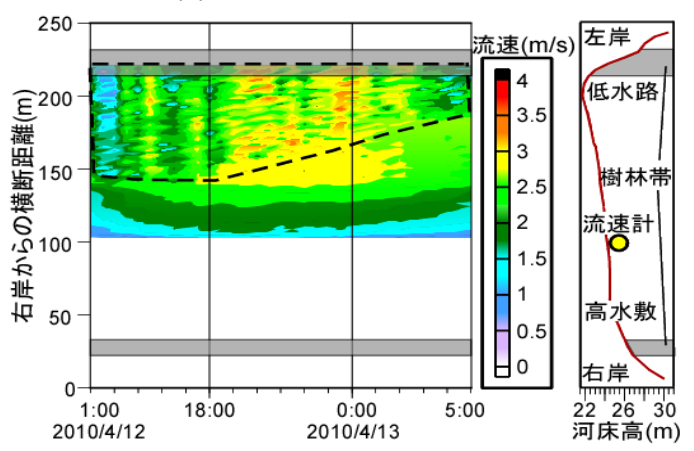

(f) 2010/4/12-13 観測値

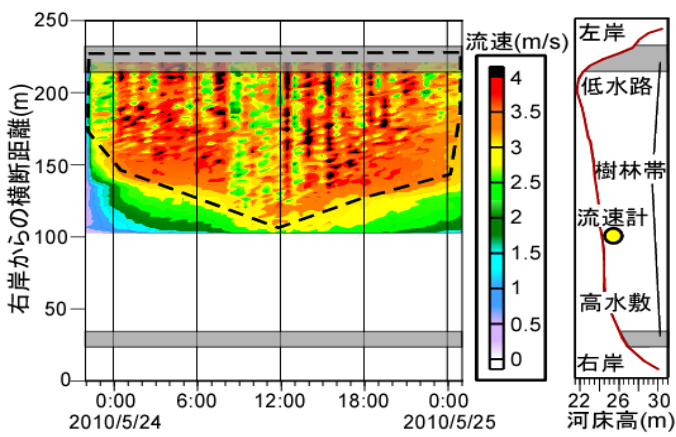

(h) 2010/5/24-25 観測值

図-5 23.6km測線における流速分布の解析值（一層流）とH-ADCP観測值との比較（経時変化） 


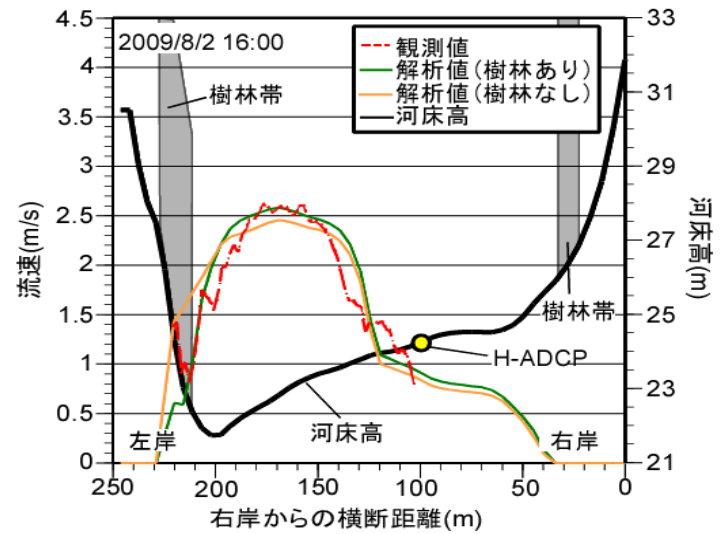

(a) $2009 / 8 / 1-2$

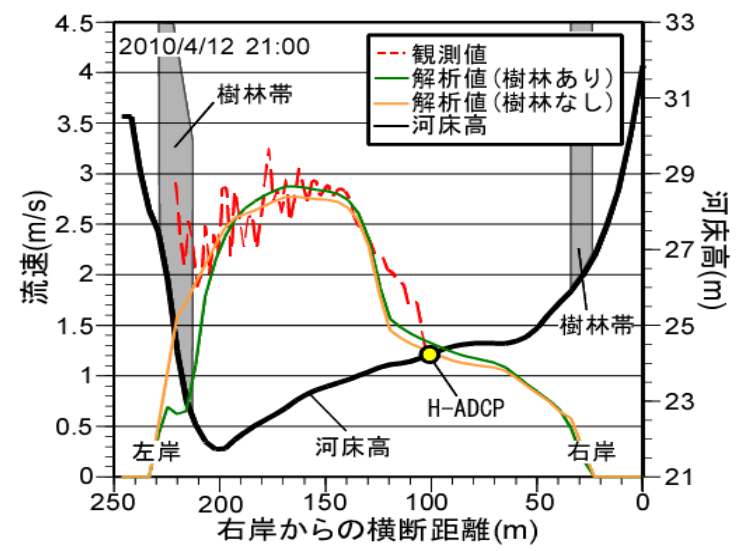

(c) 2010/4/12-13

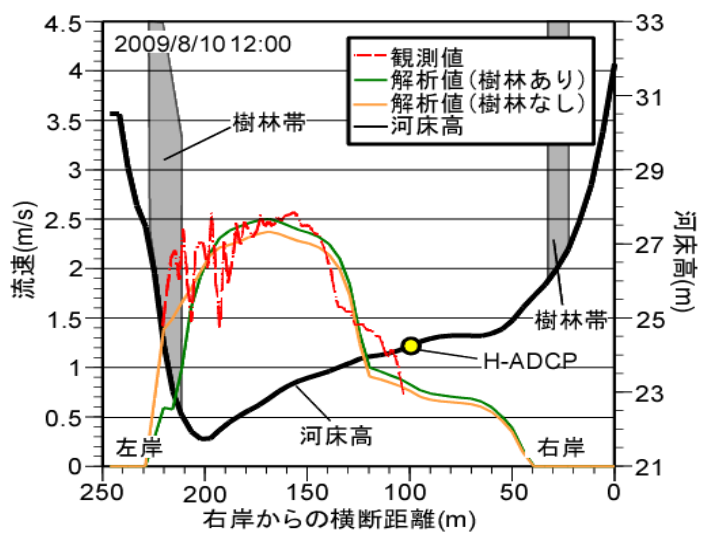

(b) $2009 / 8 / 10$

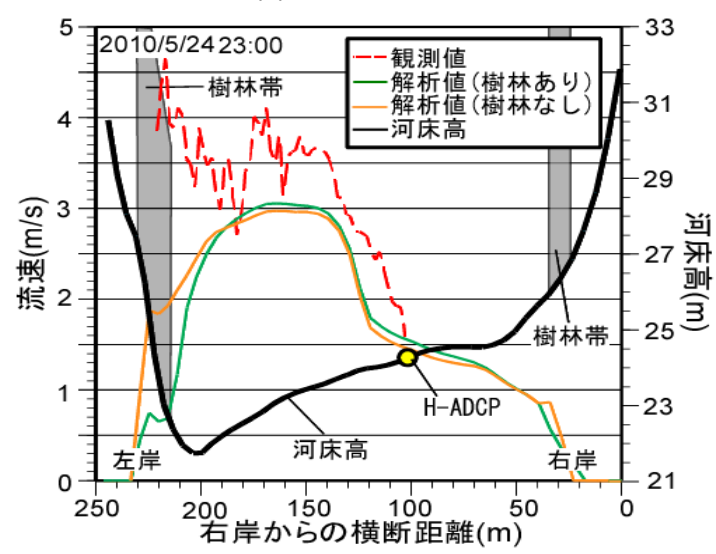

(d) 2010/5/24-25

図-6 23.6km測線における解析值（一層流）とH-ADCPIによる観測值の比較（流速の横断方向分布）

（2）流体力・底面せん断力分布と樹木倒伏実態との比較

図-8に，右岸の樹木に作用したと考えられる流体力の 推定值（数值解析）を示す. 樹林帯の上流端と樹林帯の 主流側に大きな流体力が出現している．樹林上流端であ るエリア1は水衝部に相当する．またエリア 2 は，樹林帯 の東側の低水路主流部に発生寸る強い流れの影響が原因 で発生したものと考えられる．図-8中の点は実績の倒伏 樹木を示し, 赤点が平成16年23号台風により倒伏したと 推定される樹木，黒点は2009年8月の出水により倒伏し たと推定される樹木をそれぞれ示している．実績の倒伏 箇所と数值解析から推定される大きな流体力の箇所は概 ね一致している. 主な樹木倒伏箇所は，上流端でのエリ ア1と下流端でのエリア3の大きく二カ所に分類される. エリア1は，大きな流体力の発生箇所に相当する. 前述 のように現在の樹林帯の上流側は高水敷が2008年3月に 切り下げられたために高水敷上での流れの直進性が増大 し, 小規模な出水でも樹木が倒伏したと考えられる. こ れに対し，エリア3の樹林帯下流部で樹木が倒伏してい る領域では，地盤高が低く樹木を支える支持層が薄く根 が浅いために小さな流体力でも倒伏したと考えられる.

図-9には，河床せん断力の分布を示す，樹林帯中央の 領域では流速が小さく水位が高いため, 河床せん断力は 主流部よりも小さい. しかし，樹木の倒伏に対しては， 流体抗力がもたらす倒伏モーメントに加えて河床せん断
力がもたらす局所洗掘も貢献する可能性があり，樹木倒 伏の判定に際しては流体力と河床せん断力との双方から 判断する必要がある.

\section{（3）倒伏モ一メントの検討}

倒伏モーメント $M_{\mathrm{V}}$ とその限界值 $M_{\mathrm{C}}$ との比をあらわす $M_{\mathrm{V}} / M_{\mathrm{C}}$ の分布を図-10に示寸。ここで，限界倒伏モーメ ント $M_{\mathrm{C}}$ は，樹木を直径 $20 \mathrm{~cm}$ の柱体とみなし，樹木引 き倒し試験の結果9)に基づいて単位を $\mathrm{Nm}$ に換算して求め た. $M_{\mathrm{V}} / M_{\mathrm{C}}>1$ となるとき樹木が倒伏寸ると考える. 図10 上り, 樹林帯の上流側から中央部にかけて $M_{\mathrm{V}} / M_{\mathrm{C}}>1$ となり限界值を超える倒伏モーメントが作用しており， この部分の樹木は倒伏すると判定される. 上流側では, 倒伏実績と $M_{\mathrm{V}} / M_{\mathrm{C}}$ との対応が概ね良好であることから， 倒伏の主要因は河床せん断力よりもむしろ流体力による 倒伏モーメントであると考えられる.これに対し，エリ ア3の下流端に見られる倒伏は, 根が浅く限界モーメン ト $M_{\mathrm{C}}$ 小゙さいことに起因した倒伏の可能性が高い.

\section{5. おわりに}

本研究では, H-ADCP設置後に発生した中小規模の出 水に対象として, 樹林化した河道の流れを再現するため 


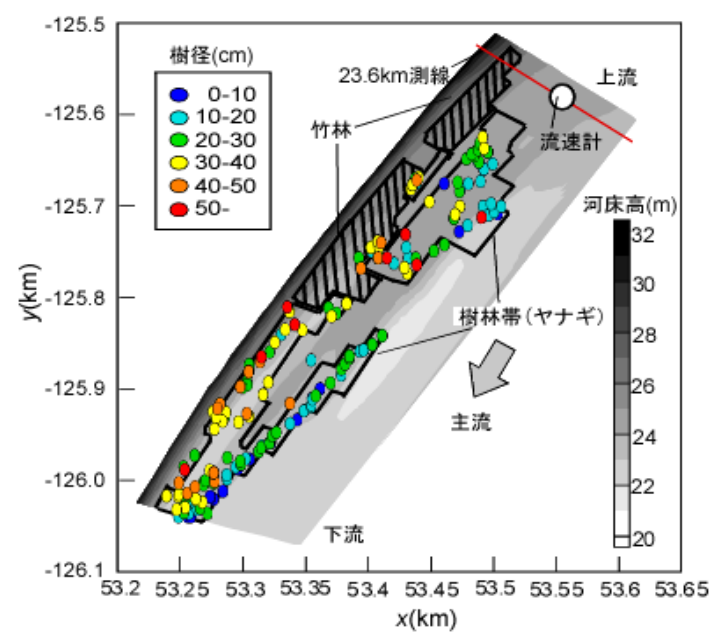

図-7 樹木の繁茂状況（2010年1月調査時点）

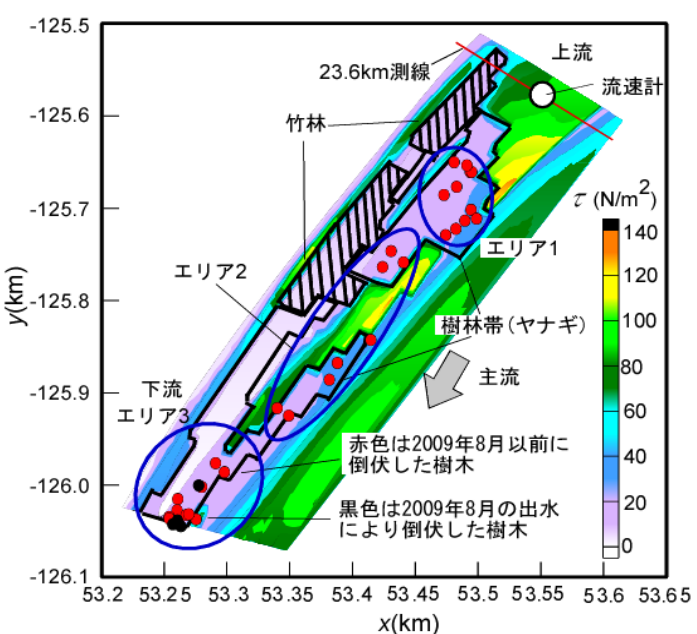

図-9＼cjkstart河床せん断力と倒伏樹木位置

の数值解析モデルを検証するとともに，樹木損壊の実態 を調査・考察した. その結果, 近年の出水で倒伏したと 考えられる樹木を多数確認することができた. 数值解析 とH-ADCPの観測值は良好に一致していること, 出水後 の現地調査から確認された樹木の倒伏実績と数值解析結 果とが良好に対応寸ることから，本モデルは出水時の河 川流を概ね再現していると判断される. 本モデルを用い ることにより，樹木一作用寸る流体力や樹林帯内の流速 分布など，現地観測だけでは得ることができない情報の 分析が可能となる. 今後, 本モデルによって, 樹林化抑 制に必要な情報分析と調査を進め, 河川整備に有用な知 見を得ることを目指す。

\section{参考文献}

1) 前野詩朗・宮内洋介・森 卓也 : 植生が旭川の洪水流に及ぼ す影響の検討，水工学論文集，第48巻，pp.757-762， 2004.

2）福岡捷二・八木澤順冶・佐々木寧・田中規夫 : 河道内樹木の 洪水破壊形態と破壞限界值の基盤土㙵条件による相違，水工 学論文集, 第52巻, pp.649-654, 2008.

3) 辻本哲郎・村上陽子・安井辰弥 : 出水による破壊機会の減少

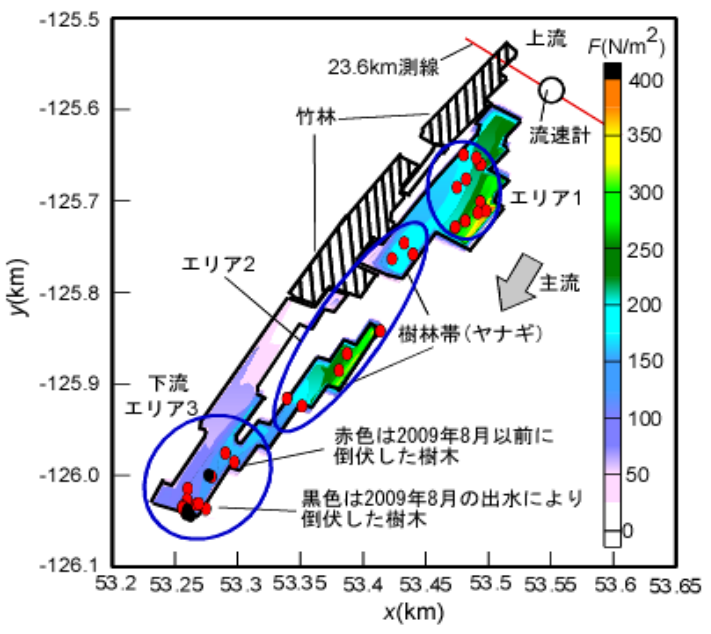

図-8＼cjkstart樹木に作用する流体力と倒伏樹木位置

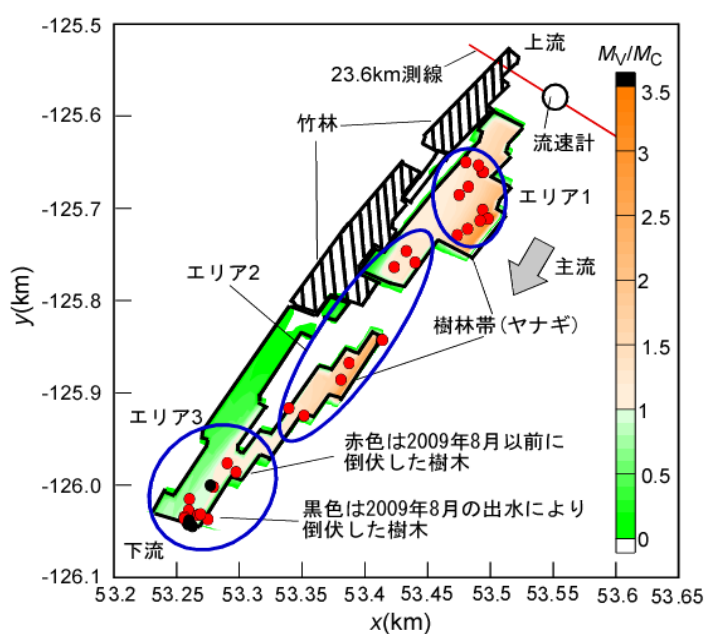

図-10 $\quad M_{\mathrm{V}} / M_{\mathrm{C}}$ と倒伏樹木位置

による河道内樹林化，水工学論文集，第45巻，pp.117-122， 2001.

4) 渡邊康玄・市川嘉輝 - 井出康郎 : 洪水時における河道内樹木 の倒伏限界，水工学論文集，第40巻，pp.53-58，1996.

5) 宮本仁志・道奥康治・神田佳一 他 : 流量変動を考慮した確 率過程モデルによる河道内樹林の消長解析, 第65回年次学術 講演会講演概要集（DVD-ROM）， 2010.

6) 道奥康治・宮本仁志・神田佳一 他 : 樹林化した河道の流況 観測之樹林内外の流況・樹木抗力の解析，河川技術論文集，

第16巻, pp.437-442, 2010.

7) 道奥康治・南条雅志 - 石垣泰輔・前野詩朗 : 捨石水制が冠水 した開水路流の二次元二層流モデル, 土木学会論文集, No.782/II-70, pp.31-50, 2005.

8) Nepf, H.M. 1999. Drag, turbulence, and diffusion in flow through emergent vegetation, Water Resources Research, Vol.35-2, pp.479-489, 1999.

9) (財)リバーフロント整備センター編 : 河川における樹木管理 の手引き, 山海堂, pp.157, 1999.

(2010.9.30受付) 